\title{
Effects of the feeding system and breed on the growth performance, biometric features, and ruminal development of feedlot goat kids
}

\author{
Efeitos do sistema de alimentação e grupo racial sobre o \\ desempenho, características de carcaça e qualidade da carne de \\ cabritos confinados
}

\author{
Pedro Paulo Sobolow de Souza ${ }^{1}$; Helen Fernanda Barros Gomes ${ }^{2 *}$; \\ Raquel Ornelas Marques 3 ; Heraldo Cesar Gonçalves ${ }^{4}$; Gil Inacio Lara Canizares; \\ Paulo Roberto de Lima Meirelles ${ }^{6}$; Giuliana Micai de Oliveira ${ }^{7}$; \\ Evelyn Prestes Brito ${ }^{8}$; Natalia Santos Leal ${ }^{9}$; Angelo Polizel Neto ${ }^{10}$
}

\begin{abstract}
The objective of this experiment was to evaluate the effect of 2 feeding systems and 5 breeding groups on the growth performance, biometric features, and stomach morphology of feedlot goat kids. The experiment utilized gender as a randomized blocking factor in a $5 \times 2$ factorial scheme. The study goats were from the Alpine, Anglo-Nubian, 1/2 Boer x Alpine, 3/4 Boer x Alpine, and 7/8 Boer x Alpine breeds. Half of the goats were fed an experimental diet, whereas the other half were given the same diet supplemented with $1.5 \mathrm{~L}$ milk daily. The kids were slaughtered after they attained $30 \mathrm{~kg}$ body weight. The 1/2 Boer x Alpine goats showed superior growth performance because they exhibiting considerable heterosis. These animals are especially easy to use given that there is no need to maintain cross-bred females ( $1 / 2$ Boer x Alpine e $3 / 4$ Boer x Alpine) in the flock. Using milk in the feed the animals does not adversely affect growth performance or biometric features. Moreover, it helps to reduce the total weight of the stomach and leads to a $51.39 \%$ savings on feed. Dietary supplementation of milk in goat feed is recommended so long as there is excess milk available on the property.

Key words: Nursing. External animal anatomy. Ruminal papillae. Rumen-reticulum.
\end{abstract}

\section{Resumo}

O experimento foi realizado com o objetivo de avaliar o efeito de dois sistemas de alimentação e de cinco grupos raciais sobre o desempenho, medidas biométricas e análise morfológica do estômago de cabritos confinados. Foi utilizado o delineamento em blocos (gênero) casualizados em esquema fatorial $5 \times 2$, sendo os grupos raciais: Alpino (A), Anglo-Nubiano (AN), 1/2 Boer x 1/2 Alpino (1/2BA), 3/4 Boer x Alpino (3/4BA) e 7/8 Boer x Alpino (7/8BA), submetidos a dois sistemas alimentares: 1,5 L

\footnotetext{
${ }^{1}$ Prof., Universidade de Rio Verde, Rio Verde, Go, Brasil. Email: pedropaulo@yahoo.com.br.

${ }^{2}$ Prof ${ }^{\mathrm{a}}$, Universidade Federal de Mato Grosso, UFMT, Sinop, MT, Brasil. E-mail: gomesh@ufmt.br

${ }^{3}$ Discente, Universidade Estadual Paulista, UNESP, Botucatu, SP, Brasil. E-mail: ra_ornelas@yahoo.com.br

${ }^{4}$ Prof. Adjunto, UNESP, Botucatu, SP, Brasil. E-mail: heraldo@fmvz.unesp.br

${ }^{5}$ Prof. Substituto, Centro de Ciências Agroveterinária, CAV, Campus de Lages, SC, Brasil. E-mail: inabra68@hotmail.com

${ }^{6}$ Prof., UNESP, Botucatu, SP, Brasil. E-mail: paulom@fmvz.unesp.br

${ }^{7}$ Discente, Escola Superior de Agricultura Luiz de Queiroz, ESALQ, Piracicaba, SP, Brasil. E-mail: giuliana.micai@hotmail.com

${ }^{8}$ Prof $^{a}$ Auxiliar I, Universidade Federal do Amazonas, UFAM, Parintins, AM, Brasil. E-mail: evelynprestes_zoo@hotmail.com

${ }^{9}$ Discente de Doutorado, UNESP, Botucatu, SP, Brasil. E-mail: nati@yahoo.com.br

${ }^{10}$ Prof., UFMT, Sinop, MT, Brasil. E-mail: polizelneto@hotmail.com

* Author for correspondence
} 
de leite/animal/dia mais dieta experimental ou apenas dieta experimental sem fornecimento de leite. Os cabritos foram abatidos após atingirem $30 \mathrm{~kg}$ de peso corporal. Os animais 1/2BA foram os que apresentaram melhor desempenho, devido à manutenção de maior heterose nesse cruzamento e que implica em facilidade de manejo por não haver necessidade de manter fêmeas cruzadas $1 / 2$ Boer x Alpine e 3/4 Boer x Alpine no rebanho. A utilização de leite na alimentação dos animais não traz prejuízos ao desempenho e medidas biométricas, e ajuda a reduzir o peso total do estômago, propiciando economia de 51,39\% no consumo da dieta, podendo ser recomendado caso haja leite excedente na propriedade.

Palavras-chave: Aleitamento. Ezoognósia. Papilas ruminais. Rúmen-retículo.

\section{Introduction}

The majority of goats raised in the Southeast Region of Brazil belong to European dairy breeds. Most are owned by small, artisanal milk producers that pasteurize the produced milk on their properties, seal it in plastic bags, and market it in the frozen form. Currently, these producers are having difficulty selling their products due to competition from industrialized milk producers who sell their milk in packages with an extended shelf life and have commercially excelled owing to this practical approach. Furthermore, the breeding facilities are frequently located far from the milk production sites, reinforcing the fact that the breeders are not interested in acquiring the produced milk.

To avoid this problem, these producers are in search of alternative methods for capitalizing on their property; among the most viable of these options is selling meat. However, to produce goat kids with better growth performance that will yield higher quality meat, it is necessary that the does mate with bucks from beef breeds. In this case, the milk that is produced is not sold, but it is rather tapped as surplus milk in order to feed the animals. However, there is lack of essential relevant information, including that regarding the race of the father, the ideal extent of cross-breeding, the viability of maintaining cross-bred females, and the replacement of the currently used dairy does with mixed breeds such as the Anglo-Nubian.

The Boer breed is preferred among these producers owing to its reputation for more effective imprinting (SKINNER, 1972; NAUDE; HOFMEYR, 1981) and a relatively more desirable build. The Anglo-Nubian breed is also a popular option, as it is fit to serve as both a source of meat and milk, in addition to the fact that it is readily available and affordable (GOMES et al., 2011).

Against this background, the objective of this study was to evaluate the effects of the breed of the male and the diet (specifically with respect to the inclusion or exclusion of milk) on the growth performance, various biometric features, and stomach morphology of feedlot kids.

\section{Materials and Methods}

The experiment was conducted at São Paulo State University in the Veterinary Medicine and Zootechnics Faculty, specifically, in the research area for goat development at Lageado Farm in Botucatu, São Paulo.

In all, 56 kids were used, specifically 29 females and 27 males, belonging to a total of 5 breeding groups. Among the males, 6 were Alpine (A), 8 were Anglo-Nubian (AN), 4 were 1/2 Boer x Alpine (1/2 BA), 4 were 3/4 Boer $x$ Alpine (3/4 BA), and 5 were 7/8 Boer x Alpine (7/8 BA). Among the females, 4 were A, 8 were AN, 6 were 1/2 BA, 5 were $3 / 4$ BA, and 6 were $7 / 8 \mathrm{BA}$. At least 2 males were used for mating for each race.

After birth, the kids were separated from their mothers and had their umbilical cords cut. They were then weighed and identified. For the 3 days after birth and 2 times each day, kids were given colostrum that had been heated in a $56{ }^{\circ} \mathrm{C}$ water bath for $60 \mathrm{~min}$. After this period, each goat was fed 1.5 L milk/day, distributed over 2 feeding times from shared buckets, until they were 60 days old. 
At this point, milk was no longer provided for half of the kids from each breeding group; these animals formed the group that was fed without milk. The animals in the other half of each group each continued to receive $1.5 \mathrm{~L}$ milk/day at a single morning feeding until they were slaughtered; these animals constitute the group that was fed with milk.

After the 2 weeks after the animals were born, they had acclimated to the 2 treatments.

The animals were kept in 10 group cages according to both their feeding system and breed until they grew to $30 \mathrm{~kg}$, at which point they were slaughtered.
The experimental diet was the same for both feeding systems, consisting of concentrate at a concentration of $700 \mathrm{~g} / \mathrm{kg}$ and coast-cross hay at a concentration of $300 \mathrm{~g} / \mathrm{kg}$ on an as-fed basis. The concentrate was composed of corn at $490 \mathrm{~g} / \mathrm{kg}$, soybean meal at $380 \mathrm{~g} / \mathrm{kg}$, cottonseed meal at 100 $\mathrm{g} / \mathrm{kg}$, limestone at $20 \mathrm{~g} / \mathrm{kg}$, and mineral salts at 10 $\mathrm{g} / \mathrm{kg}$ by dry weight. This formulation is in line with National Research Council requirements (NRC, 1981), which aim for a weight gain of $150 \mathrm{~g} /$ day. The compositions of this experimental diet and of the hay are presented in Table 1.

Table 1. The bromatological composition of the experimental diet, concentrate, and hay based on dry matter content.

\begin{tabular}{lccc}
\hline \multicolumn{1}{c}{ Components $\left(\mathrm{g} \mathrm{kg}^{-1}\right)$} & Experimental diet & Concentrate & Hay \\
\hline Dry matter & 841,1 & 832,6 & 830,7 \\
Crude Protein & 200,1 & 285,0 & 65,7 \\
Fat Extract & 27,3 & 32,2 & 11,4 \\
Ash & 59,6 & 69,1 & 40,6 \\
Crude Fiber & 187,1 & 75,2 & 324,5 \\
Not Nitrogenous Extractive & 525,9 & 538,5 & 557,8 \\
Total Digestible Nutrients & 681,3 & 785,0 & 541,1 \\
Neutral Detergente Fiber & 408,1 & 166,9 & 799,4 \\
Acid Detergente Fiber & 203,2 & 78,6 & 410,0 \\
\hline
\end{tabular}

Each month, an individual sample of milk was collected from each goat in order to determine overall composition. These samples were placed in plastic tubes containing $30 \mathrm{~mL}$ the preservative bronopol (2-bromo-2-nitropropane-1,3-diol) and were sent for analysis to the Milk Clinic of the Luiz de Quieroz College of Agriculture at the University of São Paulo in Piracicaba (Table 2).

Table 2. Average composition of the goat milk used to nurse the kids.

\begin{tabular}{lc}
\hline \multicolumn{1}{c}{ Components } & Composition $\left(\mathrm{g} \mathrm{kg}^{-1}\right)$ \\
\hline Total solids & 129,40 \\
Total dry extract & 88,00 \\
Fat & 41,40 \\
Protein & 35,50 \\
Lactose & 44,50 \\
\hline
\end{tabular}


Average daily consumption was estimated by measuring the difference between the amount of food remaining in the group cages versus the amount that was offered (Table 3).
Multiple weights were recorded, including birth weight, weight at 60 days, average daily weight gain over the first 60 days, average weight gain from weaning to slaughter, and the number of days it took to reach $30 \mathrm{~kg}$ (Days30kg).

Table 3. Average daily nutrient consumption as a function of the feeding group.

\begin{tabular}{lcccc}
\hline \multirow{2}{*}{\multicolumn{1}{c}{ Nutrient }} & Without Milk & With Milk & \\
\cline { 2 - 5 } & $\begin{array}{c}\text { Experimental diet } \\
\text { (g/day) }\end{array}$ & $\begin{array}{c}\text { Experimental diet } \\
\text { (g/day) }\end{array}$ & $\begin{array}{c}\text { Milk (1,5 L) } \\
(\mathrm{g} / \text { day })\end{array}$ & $\begin{array}{c}\text { Total } \\
\text { Consumption }\end{array}$ \\
\hline Dry Matter & 578 & 307 & 194 & 501 \\
Crude Protein & 137 & 73 & 53 & 126 \\
Fat Extract & 19 & 10 & 62 & 72 \\
Ash & 41 & 22 & - & 22 \\
Crude Fiber & 128 & 68 & - & 68 \\
Not Nitrogeneos Extract & 361 & 192 & - & 192 \\
Total Digestible Nutrients & 468 & 249 & $240^{*}$ & 489 \\
Neutral Detergente Fiber & 280 & 149 & - & 149 \\
Acid Detergente Fiber & 139 & 74 & - & 74 \\
\hline
\end{tabular}

*Based to 700Kcal of Digestible Energy (NRC, 2007).

According to the methodology established by Yáñez (2002), when the kids reached $30 \mathrm{~kg}$ in body weight, the following biometric features were measured: Body Length, the distance between the cervical-thoracic joint and the base of the tail; Anterior Height, the distance between the area of the withers and the distal end of the forelimb; Posterior Height, the distance between the sacral tuberosity, on the back, and the distal end of the hindlimb; Leg Circumference, the circumference taken at the middle part of the leg, above the femoro-tibiopatellar joint; Rump Width, the distance between the greater trochanters of the femurs; Chest Width, the distance between the faces of the scapular-humeral joints.

Before slaughtering, the animals were subjected to a solid fast for $18 \mathrm{~h}$, after which they were weighed in order to determine the body weight at slaughter. They were sent to slaughter in a commercial refrigerator.
After being eviscerated at the slaughterhouse, the gastrointestinal tract of each animal was isolated and packed in a plastic bag for morphological analysis of the stomach, following the methodology described by Costa et al. (2008). First, the component parts of the stomach were separated, sectioned, emptied, and washed with running water. Next, excess connective tissue and surrounding fat were removed in order to backlog the weights of the rumen-reticulum (RUM-RET), omasum, and abomasum. The sum of the weights of these compartments was taken as the empty weight of the stomach (Total weight). The rumen was then separated in order to evaluate its papillae framework. This was accomplished by collecting fragments of approximately $1 \mathrm{~cm}^{2}$ from the cranial sac and immediately placing them in flasks of $\mathrm{pH} 7.40 .1 \mathrm{M}$ phosphate buffered saline (consisting of $0.79 \mathrm{~g} \mathrm{NaCl}, 0.223 \mathrm{~g} \mathrm{Na}_{2} \mathrm{HPO}_{4}$, and $0.0524 \mathrm{~g} \mathrm{NaH}_{2} \mathrm{PO}_{4}$ dissolved in water up to a volume of $100 \mathrm{~mL}$ ) for $30 \mathrm{~min}$ beforehand. 
The samples were then evaluated with respect to the number of papillae per given area (number $\left./ \mathrm{cm}^{2}\right)$ on the wall of the rumen and the average area $\left(\mathrm{cm}^{2}\right)$ of the papillae. Papillae concentrations for each fragment were determined by averaging the counts of 3 separate observers and dividing that value by the area. After the fragments were counted, 12 papillae were taken at random from each fragment and placed in a Petri dish in order to measure their area. The areas of the fragments and the papillae were measured using digital images obtained through the free UTHSCSA ImageTool image processing and analysis software (RESENDE JÚNIOR et al., 2006).

The experiment was conducted using gender as a randomized blocking factor and analyzed by factorial analysis of variance. The factorial consisted of the 5 breeding groups and the 2 feeding groups. Measurements were compared using Tukey's test $(\mathrm{P}<0.05)$. Analysis of the data was accomplished using the SAEG program (UFV, 2000).

The model used to analyze the morphological characteristics of the stomach was combined with the PVA co-variable.

\section{Results and Discussion}

Body weight was influenced by breeding group; ANs were lighter than 3/4 BAs, though similar to the others (Table 4). This could have occurred because of the greater proportion of AN does that gave birth to only one kid. Alternatively, this could simply be a characteristic inherent in each race, as suggested by Rodrigues (2009), who showed that BAs were born heavier than mixed-race ANs. No interaction was observed between the sources of group breed variation and the feeding method.

After 60 days, the differences between the ANs and the other groups were far greater (Table 4), which could be a result of their lower weight at birth. Moreover, this breed did not present the same capacity for muscle development as did the mixed-breed groups; this is due to their lower weight development, according to values reported by Araújo et al. (1999), who observed that A kids were heavier than their AN counterparts 56 days after birth.

Table 4. The averages of birth weight, weight at 60 days, average daily weight gain over the first 60 days, average weight gain from day 60 until reaching $30 \mathrm{~kg}$, and the number of days it took to reach $30 \mathrm{~kg}$ for feedlot kids divided by their breed and feeding method.

\begin{tabular}{|c|c|c|c|c|c|c|}
\hline \multicolumn{5}{|c|}{ Racial group } & \multicolumn{2}{|c|}{ Feeding system } \\
\hline Alpine & AN & 1/2BA & 3/4BA & 7/8BA & Without milk & With milk \\
\hline \multicolumn{7}{|c|}{ Birth weight $-(\mathrm{kg})$} \\
\hline $3,67 \mathrm{ab}$ & $3,18 \mathrm{~b}$ & $3,74 \mathrm{ab}$ & $3,93 \mathrm{a}$ & $3,56 \mathrm{ab}$ & 3,65 & 3,58 \\
\hline \multicolumn{7}{|c|}{ Weight at 60 days $-(\mathrm{kg})$} \\
\hline 13,62 a & $10,53 \mathrm{~b}$ & $13,89 \mathrm{a}$ & $12,30 \mathrm{a}$ & $12,40 \mathrm{a}$ & 12,64 & 12,45 \\
\hline \multicolumn{7}{|c|}{ Averave gain until 60 days - (g/day) } \\
\hline $165,90 \mathrm{a}$ & $122,54 \mathrm{c}$ & $169,15 \mathrm{a}$ & $139,38 \mathrm{bc}$ & $147,28 \mathrm{ab}$ & 149,87 & 147,84 \\
\hline \multicolumn{7}{|c|}{ Average gain after 60 days, until $30 \mathrm{~kg}$ body weight - (g/day) } \\
\hline $123,71 \mathrm{bc}$ & $113,77 \mathrm{c}$ & $175,29 \mathrm{a}$ & $149,45 \mathrm{ab}$ & $141,58 \mathrm{~b}$ & 136,31 & 145,21 \\
\hline \multicolumn{7}{|c|}{ Days to $30 \mathrm{~kg}$ body weight - (day) } \\
\hline $197,62 \mathrm{~b}$ & $238,56 \mathrm{a}$ & $154,08 \mathrm{c}$ & $181,24 \mathrm{bc}$ & $189,73 \mathrm{bc}$ & 194,18 & 190,32 \\
\hline
\end{tabular}

* Means followed by different letters in the lines, different by the Tukey test $(\mathrm{P}<0,05)$. 
Avarege gain until 60 days was 148.85 g/day, greater than the average gain after 60 days that value of $140.76 \mathrm{~g} /$ day. This indicates a slowing in the growth rate as the animals continue to grow, which is in agreement with the animal growth curve proposed by Owens et al. (1993).

A and 1/2 BA kids showed a greater avarege gain until 60 days value than AN and 3/4 BA did (Table 4), indicating an elevated growth rate for the dairy breeds and maximum heterosis for the 1/2 BA breed. This is in agreement with Bueno (2011), who found no difference in average weight gain for Saanen or $1 / 2$ Boer x Saanen kids.

The lower growth performance of the following generations of mixed-breed groups can be explained by the loss of heterosis. According to Pereira (2001), second-generation cross-bred populations retain just $50 \%$ of the heterosis observed in the first generation.

After weaning the animals, the $1 / 2$ BAs showed greater average gain after 60 days than the Alpines, ANs, and 7/8 BAs. This greater performance, both before and after weaning, resulted in the $1 / 2$ BAs having the lowest days to $30 \mathrm{~kg}$ Body weight value and, therefore, being slaughtered first. The AN kids showed inferior growth performance compared to the BAs; this is similar to data presented by Gibb et al. (1993), who showed that AN kids gave inferior growth performance when compared to British Saanen and British Saanen x Boer cross-breeds that were weaned at 58 days and were slaughtered with a body mass of $28 \mathrm{~kg}$. Although cross-breeding Boers with large milk breeds gives contradictory results (GIBB et al., 1993; GOONEWARDENE et al., 1998; URGE et al., 2004; MENEZES et al., 2012), in this study, the $1 / 2$ BAs possibly showed the best growth performance due to the generous feeding conditions of the study, as evidenced by weight gain greater than $150 \mathrm{~g} /$ day; this further supports the argument that Boer hybrids excel in favorable environmental conditions (RODRIGUES, 2009).

The breed influenced the days to $30 \mathrm{~kg}$ body weight value, such that generally, mixed-breed animals needed less time to grow to the necessary weight for slaughter; this agrees with results obtained by Gibb et al. (1993), who showed similar results in a study of feedlot British Saanen, British Saanen x Boer hybrids, and Anglo-Nubians raised to slaughter at $28 \mathrm{~kg}$. Menezes (2012) came to the same determination when comparing $1 / 2 \mathrm{BA}$ kids to As.

The observed conversion of feed to weight and overall feeding efficiency are similar to those in the literature (Table 5), which vary from 3.15 to 10.80 $\mathrm{kg}$ of feed/ $\mathrm{kg}$ of body weight gain, depending on the measured phase, (MENEZES, 2005) and from 85 to $263 \mathrm{~g}$ of weight gain $/ \mathrm{kg}$ of feed, respectively (PRIETO et al., 2000; CAMERON et al., 2001; URGE et al., 2004; NGWA et al., 2009).

The observed slaughter body weight values for the treatments without and with milk groups were, respectively, 29.78 and $30.74 \mathrm{~kg}$ for As, 30.10 and $30.94 \mathrm{~kg}$ for ANs, 31.92 and $30.78 \mathrm{~kg}$ for $1 / 2 \mathrm{BAs}$, 30.12 and $31.25 \mathrm{~kg}$ for $3 / 4 \mathrm{BAs}$, and 31.63 and $30.66 \mathrm{~kg}$ for $7 / 8 \mathrm{BAs}$.

Use of the experimental diet resulted in reduction in the per-kilogram cost of meat produced for the With milk group trial-it was 51.39\% lower than that for the without milk group (Table 6); this may be attributed to the excess cost of $1,988.81 \mathrm{~kg}$ of feed. However, the use of milk can only be justified if excess milk is produced during breeding.

Differences between the feeding groups did not influence any of the biometric features (Table 7) except for leg circumference, in which case there was an interaction with the breed; for with milk group animals, As gave lower values than ANs, 3/4 BAs, and 7/8 BAs, while showing no difference from 1/2 BAs. Likewise, with milk group Alpines and $1 / 2$ BAs had reduced leg circumference values when compared to the without milk group animals (Table 8).

Overall, Alpine and AN kids were longer and taller than hybrid Boers, although the hybrids did show greater LP values. 
Table 5. Individual average consumption of the experimental diet and of total milk, as well as feed conversions with respect to both feeding groups and breeding groups.

\begin{tabular}{|c|c|c|c|c|c|}
\hline \multirow[b]{2}{*}{$\begin{array}{l}\text { Racial } \\
\text { Group }\end{array}$} & \multirow[b]{2}{*}{$\begin{array}{l}\text { Feeding } \\
\text { system }\end{array}$} & \multicolumn{4}{|c|}{ Variables } \\
\hline & & $\begin{array}{l}\text { Feed intake } \\
\text { (Experimental } \\
\text { diet) }(\mathrm{kg})\end{array}$ & $\begin{array}{c}\text { Feed efficiency - diet } \\
\text { (kg diet/kg Body } \\
\text { weight) }\end{array}$ & $\begin{array}{l}\text { Feed intake } \\
\text { (Milk) (liter) }\end{array}$ & $\begin{array}{c}\text { Feed efficiency - milk } \\
\text { (L milk/kg body } \\
\text { weight) }\end{array}$ \\
\hline \multirow{2}{*}{ Alpine } & Without milk & 130,83 & 8,03 & & \\
\hline & With milk & 78,16 & 4,33 & 229,5 & 12,72 \\
\hline \multirow[b]{2}{*}{ AN } & Without milk & 152,52 & 7,78 & & \\
\hline & With milk & 67,11 & 3,38 & 286,5 & 14,44 \\
\hline \multirow{2}{*}{$1 / 2 \mathrm{BA}$} & Without milk & 118,28 & 6,06 & & \\
\hline & With milk & 58,86 & 3,24 & 153,0 & 8,43 \\
\hline \multirow{2}{*}{ 3/4BA } & Without milk & 119,61 & 6,11 & & \\
\hline & With milk & 77,86 & 3,97 & 210,0 & 10,71 \\
\hline \multirow{2}{*}{ 7/8BA } & Without milk & 134,41 & 6,87 & & \\
\hline & With milk & 69,57 & 3,57 & 215,1 & 11,03 \\
\hline
\end{tabular}

Table 6. Consumption, cost of production, total weight gain, and feed efficiency of the experimental diet and milk with respect to feeding groups.

\begin{tabular}{lcccc}
\hline \multirow{2}{*}{\multicolumn{1}{c}{ Variables }} & \multicolumn{4}{c}{ Feeding System } \\
\cline { 2 - 5 } & \multicolumn{2}{c}{ Without milk } & \multicolumn{2}{c}{ With milk } \\
& Quantity & R $\$$ & Quantity & R $\$$ \\
\hline Experimental diet intake $(\mathrm{kg})$ & $3.870,12$ & $2.090,00$ & $1.881,31$ & $1.016,00$ \\
Milk intake (L) & & & $6.120,00$ & $8.568,00$ \\
Total Cost & & $2.090,00$ & & $9.584,00$ \\
Total body weight gain $(\mathrm{kg})$ & 550,90 & & 515,50 & \\
Feed efficiency (g gain $/ \mathrm{kg}$ food) & 142 & & 274 & 18,59 \\
Production cost $/ \mathrm{kg}$ body weight (with milk cost) & & 3,79 & & 1,97 \\
Production cost $/ \mathrm{kg}$ body weight (without milk cost) & & 3,79 & & \\
\hline
\end{tabular}

Source: farmapoint.com.br; mfrural.com.br; safras e mercado, pecuária.com.br All such Were based hair quotations to average price of products in 2011.

Table 7. Averages for Body Length, Anterior Height, Posterior Height, Rump Width, and Chest Width of feedlot kids as a function of breeding and feeding groups.

\begin{tabular}{|c|c|c|c|c|c|c|}
\hline \multicolumn{5}{|c|}{ Racial Group } & \multicolumn{2}{|c|}{ Feeding System } \\
\hline Alpine & AN & $1 / 2 \mathrm{BA}$ & $3 / 4 \mathrm{BA}$ & $7 / 8 \mathrm{BA}$ & Without milk & With milk \\
\hline \multicolumn{7}{|c|}{ Body Length $(\mathrm{cm})$} \\
\hline $66,69 \mathrm{a}$ & $65,64 \mathrm{ab}$ & $65,34 \mathrm{ab}$ & $63,38 \mathrm{~b}$ & $63,24 \mathrm{~b}$ & 64,78 & 64,93 \\
\hline \multicolumn{7}{|c|}{ Anterior Height $(\mathrm{cm})$} \\
\hline $66,04 \mathrm{a}$ & $63,52 \mathrm{ab}$ & $62,07 \mathrm{bc}$ & $60,40 \mathrm{~cd}$ & $59,12 \mathrm{~d}$ & 62,51 & 61,95 \\
\hline \multicolumn{7}{|c|}{ Posterior Height $(\mathrm{cm})$} \\
\hline $66,32 \mathrm{a}$ & $64,89 \mathrm{a}$ & $62,04 \mathrm{~b}$ & $61,10 \mathrm{~b}$ & $59,97 \mathrm{~b}$ & 62,97 & 62,76 \\
\hline \multicolumn{7}{|c|}{ Rump Width (cm) } \\
\hline 16,00 & 15,92 & 16,79 & 16,25 & 17,05 & 16,61 & 16,02 \\
\hline \multicolumn{7}{|c|}{ Chest Width (cm) } \\
\hline $16,56 \mathrm{~b}$ & $16,24 \mathrm{~b}$ & $18,13 \mathrm{a}$ & $17,75 \mathrm{a}$ & $18,13 \mathrm{a}$ & 17,56 & 17,17 \\
\hline
\end{tabular}

* Means followed by different letters in the lines, different by the Tukey test $(\mathrm{P}<0,05)$. 
Furthermore, as the Boer race becomes more dominant through cross-breeding, these differences become more pronounced. This effect of decreased height could be explained by the fact that this livestock breed type is composed of more compact animals, depending on how they are selected for meat production. The opposite has been observed in animals for milking or mixed use - these tend to be longer and skinnier (MEDEIROS, 2009). These results are similar to those obtained by Gomes et al. (2011) and by Menezes et al. (2012).

The feeding groups showed differences in all of the compartments of the stomach; the total weight of the stomach, as well as the individual RUM-RET and omasum values, was greater in without milk kids, while the weight of the abomasum was greater for the with milk group.

This effect could be attributed to the fact that the without milk group consumed more solid food, which resulted in greater stimulation of the RUMRET and omasum compartments. Meanwhile, the greater weight of the abomasum in the with milk group animals was the result of greater physical stimulation in that compartment, seeing as how that is the site where milk is digested. These results are in line with those obtained by Potchoiba et al. (1990), who studied feedlot kids, slaughtered 5 months after birth, that were either initially provided with feed or that only consumed milk; the omasum was heavier in those animals that only ate solid feed, meaning that liquid diets do not contribute to the development of this compartment. Similarly, Amaral (2002) compared 3 groups of animals that were fed mashed, pelleted, or extruded food, and concluded that the feeding system that provoked the least physical stimulus on the walls of the RUM-RET, namely the mashed food, was the one that resulted in the lowest weight for these compartments.

Breed influenced both total stomach weight and omasum weight (Table 8); specifically, AN kids were lighter in both respects than $1 / 2$ BA kids, though they were similar to the others. This result was not significantly affected by the abomasum and RUMRET, even though the two were also slightly heavier for AN kids. This is in agreement with observations by Ferreira (2010), who reported a difference in total stomach weight when comparing kids from different breeds that were born in confinement and slaughtered between 20 and $25 \mathrm{~kg}$. However, the results of this experiment run counter to those obtained by Sousa Monte et al. (2007) and Oliveira (2009), neither of whom observed any influence of breed on stomach weight. The first of these papers reported on hybrids resulting from the mixing of either ANs or Boers with undefined breeds that were subsequently slaughtered at an average weight of $28 \mathrm{~kg}$, while the second studied 3/4 Boer x $1 / 4$ Saanens and pure Saanens that were slaughtered at an average weight of $29.50 \mathrm{~kg}$.

Table 8. Average Leg Circumference values of feedlot kids as a function of breeding and feeding groups.

\begin{tabular}{lccccc}
\hline \multirow{2}{*}{ Feeding system } & \multicolumn{5}{c}{ Racial Group } \\
\cline { 2 - 5 } & Alpine & AN & 1/2BA & $3 / 4 \mathrm{BA}$ & $7 / 8 \mathrm{BA}$ \\
\hline Without milk & $36,00 \mathrm{aA}$ & $35,25 \mathrm{aA}$ & $38,20 \mathrm{aA}$ & $36,60 \mathrm{aA}$ & $37,33 \mathrm{aA}$ \\
With milk & $32,90 \mathrm{bB}$ & $36,75 \mathrm{aA}$ & $35,00 \mathrm{abB}$ & $38,00 \mathrm{aA}$ & $38,30 \mathrm{aA}$ \\
\hline
\end{tabular}

* Means followed by at least one same letter in the rows and columns in the case, do not differ ( $\mathrm{P}>0.05)$ by Tukey test.

The feeding system influenced papillae area (Table 9), with the biggest values observed in SL animals. These increased values are the result of the greater ingestion of solid feed, seeing how this is the most important agent with respect to the development of the rumen. The development of the papillae in the rumen is influenced by the presence of volatile fatty acids resulting from carbohydrate 
fermentation (MGASA et al., 1994), which in turn are present in greater amounts in animals that consume more solid foods. Previous work from the 50s and 60s highlighted short-chain fatty acids, especially butyric and propionic acid, as the key factors in the development of the ruminal epithelium (WARNER et al., 1956; TAMATE et al., 1962).
Breed influenced papillae concentration (Table 9); specifically, As showed a greater number of papillae per $\mathrm{cm}^{2}$ than $1 / 2 \mathrm{BAs}$ did, while ANs, 3/4 BAs, and 7/8 BAs showed no differences in their number of papillae with respect to other groups. This might be explained by the fewer number of days that $1 / 2$ BAs needed to reach the necessary weight for slaughtering - in other words, living for less time can influence the number of papillae in the rumen.

Table 9. Average weights for the entire stomach, RUM-RET, omasum, and abomasum, as well as the average number of papillae per $\mathrm{cm}^{2}$ and papillae area for feedlot kids as a function of breeding and feeding groups.

\begin{tabular}{|c|c|c|c|c|c|c|}
\hline \multicolumn{5}{|c|}{ Racial Group } & \multicolumn{2}{|c|}{ Feeding system } \\
\hline Alpine & AN & $1 / 2 \mathrm{BA}$ & 3/4BA & 7/8BA & Without milk & With milk \\
\hline \multicolumn{7}{|c|}{ Entire stomach $(\mathrm{kg})$} \\
\hline $0,7287 \mathrm{ab}$ & $0,6991 \mathrm{~b}$ & 0,7983 a & $0,7901 \mathrm{ab}$ & $0,7297 \mathrm{ab}$ & $0,8000 \mathrm{a}$ & $0,6980 \mathrm{~b}$ \\
\hline \multicolumn{7}{|c|}{ RUM- RET (kg) } \\
\hline 0,5426 & 0,5251 & 0,5822 & 0,5906 & 0,5473 & $0,6119 \mathrm{a}$ & $0,5032 \mathrm{~b}$ \\
\hline \multicolumn{7}{|c|}{ Omasum (kg) } \\
\hline $0,0640 \mathrm{ab}$ & $0,0531 \mathrm{~b}$ & $0,0720 \mathrm{a}$ & $0,0524 \mathrm{~b}$ & $0,0501 \mathrm{~b}$ & $0,0686 \mathrm{a}$ & $0,0478 \mathrm{~b}$ \\
\hline \multicolumn{7}{|c|}{ Abomasum (kg) } \\
\hline 0,1228 & 0,1208 & 0,1440 & 0,1471 & 0,1323 & $0,1199 \mathrm{~b}$ & $0,1469 \mathrm{a}$ \\
\hline \multicolumn{7}{|c|}{ Average number of papillae/cm2 (no) } \\
\hline $57,96 \mathrm{a}$ & $48,68 \mathrm{ab}$ & $35,98 \mathrm{~b}$ & $48,46 \mathrm{ab}$ & $47,25 \mathrm{ab}$ & 47,28 & 48,05 \\
\hline \multicolumn{7}{|c|}{ Papillae area $\left(\mathrm{cm}^{2}\right)$} \\
\hline 0,12 & 0,14 & 0,16 & 0,12 & 0,15 & $0,17 \mathrm{a}$ & $0,11 \mathrm{~b}$ \\
\hline
\end{tabular}

There is minimal research relating to ruminal papillae in goats. Wang et al. (2009) tested 3 different feeding systems and concluded that each had a distinct effect on papillae area and density. On the other hand, Moraes et al. (2011) did not observe any effect from feeding systems on ruminal papillae development or density in goats. This suggests that this topic merits further attention in future studies.

\section{Conclusions}

The 1/2 BA breeding group is recommended as the source for goat kids intended for meat production. It is best to begin with Boer goats and milk-producing As, because this would provide the best means of developing this stock and the easiest way to manage themgiven that it would eliminate the need to keep mixed breeds in the flock.

The use of excess milk is recommended, given that it does not adversely affect the animals' growth performance or biometric features. In addition, it helps to reduce the total weight of the stomach, while providing a savings of $51.39 \%$ on feed.

\section{References}

AMARAL, C. M. C. do. Extrusão e peletização de ração completa: efeitos no desempenho, na digestibilidade e no desenvolvimento das câmaras gástricas de cabritos Saanen. 2002. Dissertação (Mestrado em Zootecnia) - Faculdade de Ciências Agrárias e Veterinárias. Universidade Estadual Paulista, Jaboticabal. 
ARAÚJO, A. M. de; BARROS, N. N.; SILVA, F. L. R. Peso e ganho de peso em crias Anglo-Nubiano, Pardo Alpina e Saanen na fase de aleitamento em Sobral, Ceará. Revista Científica de Produção Animal, Teresina, v. 1, n. 2, p. 131-138, 1999.

BUENO, M. S. Desempenho e características de carcaça de cabritos Saanen e mestiços Boer x Saanen abatidos com diferentes pesos. Nova Odessa: Monografias.com S.A., 2011. Disponível em: <http://br.monografias. com/trabalhos/desempenho-caracteristicas-carcaca/ desempenho-caracteristicas-carcaca.shtml $>$. Acesso em: 16 maio. 2016.

CAMERON, M. R.; LUO, J.; SAHLU, T.; HART, S. P.; GOETSCH, A. L. Growth and slaughter traits of Boer x Spanish, Boer x Angora and Spanish goat consuming a concentrate-based diet. Journal Animal Science, Champaign, IL, v. 79, n. 6, p. 1423-1430, 2001.

COSTA, S. F.; PEREIRA, M. N.; MELO, L. Q.; CALIARI, M. V.; CHAVES, M. L. Alterações morfológicas induzidas por butirato, propionato e lactato sobre a mucosa ruminal e a epiderme de bezerros - I aspectos histológicos. Arquivo Brasileiro de Medicina Veterinária e Zootecnia, Belo Horizonte, v. 60, n. 1, p. $1-9,2008$.

FERREIRA, L. Desempenho produtivo e características de carcaça de caprinos com diferentes composições raciais. 2010. Dissertação (Mestre em Ciências) - Universidade Federal Rural do Rio de Janeiro, Seropédica.

GIBB, M. J.; COOK, J. E.; TREACHER, T. T. Performance of British Saanen, Boer x British Saanen and Anglo-Nubian castrated male kids from 8 weeks to slaughter at 28, 33 and $38 \mathrm{~kg}$ live weight. Animal Production, Queensland, v. 57, n. 2, p. 263-271, 1993.

GOMES, H. F. B.; MENEZES, J. J. L. de; GONÇALVES, H. C.; CANIZARES, G. I.; MEDEIROS, B. B. L.; POLIZEL NETO, A.; LOURENÇON, R. V.; CHÁVARI, A. C. T. Características de carcaça de caprinos de cinco grupos raciais criados em confinamento. Revista Brasileira de Zootecnia, Viçosa, MG, v. 40, n. 2, p. 411417, 2011.

GOONEWARDENE, L. A.; DAY, P. A.; PATRICK, N.; SCHEER, H. D.; PATRICK, D.; SULEIMAN, A. A preliminary evaluation of growth and carcass traits in Alpíne and Boer goat crosses. Canadian Journal of Animal Science, Sherbrooke, v. 78, n. 2, p. 229-232, 1998.

MEDEIROS, L. F. D. Julgamento de caprinos $e$ ovinos: julgamento animal. Seropédica: Universidade Federal Rural do Rio de Janeiro, Instituto de Zootecnia,
Departamento de Reprodução e Avaliação Animal. 2009. $31 \mathrm{p}$.

MENEZES, J. J. L. Desempenho e características de carcaça de caprinos de diferentes grupos raciais e idade ao abate. 2005. Dissertação (Mestrado em Zootecnia) - Faculdade de Medicina Veterinária e Zootecnia. Universidade Estadual Paulista, Botucatu.

MENEZES, J. J. L.; GONÇALVES, H. C.; CANIZARES, G. I. L.; RODRIGUES, L.; MEDEIROS, B. B. L.; GOMES, H. F. B.; MARQUES, R. O.; EMERSON, M. $\mathrm{S}$. Ganho de peso e medidas biométricas de caprinos jovens em função do grupo racial, peso de abate e sexo. Veterinária e Zootecnia, Botucatu, v. 19, n. 4, p. 574-583, 2012.

MGASA, M. N.; BASSE, A.; ARNBJERG, J.; ORGENSEN, J.; THAMSBORG, S. M.; FOGH, J. Influence of diet on forestomach, bone and digital development in young goats. Small Ruminant Research, Amsterdam, v. 14, n. 1, p. 35-41, 1994.

MORAES, A. C. A. de; BATISTA, A. M. V.; PONTES FILHO, N. Substituição de milho por casca de soja em dietas à base de palma forrageira (Nopalea cochenillifera, Salm Dick) para caprinos: tamanho do estômago e número de papilas ruminais. Brasília: [s.n.], 2011. Disponível em: <http://www.abz.org.br/tag/ caprino/index.4.html>. Acesso em: 25 jun. 2011.

NATIONAL RESEARCH COUNCIL - NRC. Nutrient requirements of goats. Washington, D. C.: Washington: National Academic Press, 1981. 91 p.

. Nutrient requirements of small ruminants. Sheep, goat, cervids and New World Camelids. Washington, D. C.: National Academic Press, 2007. 362 p.

NAUDE, R. T.; HOFMEYR, H. S. Meat production. London, New York, Toronto, Sydney, San Francisco: Ed. C. Gall. Academic Press, 1981. Chapter 9, 612 p.

NGWA, A. T.; DAWSON, L. J.; PUCHALA, R.; DETWEILER, G. D.; MERKEL, R. C.; WANG, Z.; TESFAI, K.; SAHLU, K.; FERREL, C. L.; GOETSCH, A. L. Effects of breed and diet on growth and body composition of crossbred Boer and Spanish wether goats. Journal of Animal Science, Champaign, v. 87, n. 9, p. 2913-2923, 2009.

OLIVEIRA, R. V. Avaliação e utilização de silagens de grão úmido de milho sobre o desempenho $e$ características de carcaça de caprinos. 2009. Tese (Doutorado em Zootecnia) - Faculdade de Ciências Agrárias e Veterinárias. Universidade Estadual Paulista, Jaboticabal. 
OWENS, F. N.; DUBESKI, P.; HANSON, C. F. Factors that alter the growth and development of ruminants. Journal of Animal Science, Champaign, v. 71, n. 11, p. 3138-3150, 1993.

PEREIRA, J. C. C. Melhoramento genético aplicado à produção animal. Belo Horizonte: FEPMVZ, 2001. 555 p.

POTCHOIBA, M. J.; LU, C. D.; PINKERTON, F.; SAHLU, T. Effects of all-milk diet on weight gain, organ development, carcass characteristics and tissue composition, including fatty acids and cholesterol contents, of growing male goats. Small Ruminant Research, Amsterdam, v. 3, p. 583-592, 1990.

PRIETO, I.; GOETSCH, A. L.; BANSKALIEVA, V.; CAMERON, M.; PUCHALA, R.; SAHLU, T.; DAWSON, L. J.; COLEMAN, S. W. Effects of dietary protein concentration on postweaning growth of Boer crossbred and Spanish goat wethers. Journal of Animal Science, Champaign, v. 78, n. 11, p. 2275-2281, 2000.

RESENDE JÚNIOR, J. C.; ALONSO, L. S.; PEREIRA, M. N. Effect of the feeding pattern on rumen wall morphology of cows and sheep. Brazilian Journal of Veterinary Research and Animal Science, São Paulo, v. 43, n. 4, p. 526-536, 2006.

RODRIGUES, L. Sistemas de produção de caprinos de leite e carne em pasto ou confinamento. 2009. Tese (Doutorado em Zootecnia) - Faculdade de Medicina Veterinária e Zootecnia. Universidade Estadual Paulista, Botucatu.

SKINNER, J. D. Utilization of the Boer goat for intensive animal production. Tropical Animal Health and Production, Netherlands, v. 4, n. 2, p. 120-128, 1972.
SOUSA MONTE, A. L. de; SELAIVE-VILLARROEL, A. B.; OLIVEIRA, A. N.; PEREZ, J. R. O.; ZAPATA, J. F. F.; RAMOS, R. E. Rendimento das vísceras de cabritos mestiços Anglo x SRD e Boer x SRD ${ }^{1}$. Ciência e Agrotecnologia, Lavras, v. 31, n. 1, p. 223-227, jan./ fev. 2007.

TAMATE, H.; MCGILLIARD, A. D.; JACOBSON, N. L.; GETTY, R. Effect of various dietaries on the anatomical development of the stomach in the calf. Journal of Dairy Science, Madison, v. 45, n. 3, p. 408420, 1962.

UNIVERSIDADE FEDERAL DE VIÇOSA - UFV. Sistema de análises estatísticas e genéticas - SAEG. Versão 8.0. Viçosa, MG, 2000. 142 p.

URGE, M.; MERKEL, R. C.; SAHLU, T.; ANIMUT, G.; GOESTSCH, A. L. Growth performance by Alpine, Angora, Boer and Spanish wether goats consuming 50 or $75 \%$ concentrate diets. Small Ruminant Research, Amsterdam, v. 55, n. 1-3, p. 149-158, 2004.

WANG, Y. H.; XU, M.; WANG, F. N.; YU, Z. P.; YAOA, J. H.; ZAN, L. S.; YANG, F. X. Effect of dietary starch on rumen and small intestine morphology and digesta $\mathrm{pH}$ in goats. Livestock Science, Miles City, v. 122, n. 1, p. 48-52, 2009.

WARNER, R. G.; FLATT, W. P.; LOOSLI, J. K. Dietary factors influencing the development of the ruminant stomach. Journal of Agricultural and Food Chemistry, Washington, v. 4, p. 788-792, 1956.

YÁÑEZ, E. A. Desenvolvimento relativo dos tecidos e características de carcaça de cabritos Saanen, com diferentes pesos e níveis nutricionais. 2002. Tese (Doutorado em Zootecnia) - Faculdade de Ciências Agrárias e Veterinárias. Universidade Estadual Paulista, Jaboticabal. 
